Schweiz. Z. Path. Bakt. 1955;18:I-VIII

\title{
Contents, Vol. 18, 1955
}

\author{
H.BERGSTRAND, Stockholm \\ R.BIELING, Wien \\ H.CHÍARI, Wien \\ M. DJURISIC, Beograd \\ J. FIRKET, Liège \\ E. GRASSET, Geneve \\ C. HALLAUER, Bern \\ E. LETTERER, Tubingen \\ EDITORES
}

A. LINDAU, LuПd E. G. NAUCK, Hamburg J. L. NICOD, Lausanne CH. 0BERL1NG. Pans A. L. OLITZKI, Jerusalem E. RUTISHAUSER, Geneve H. SMETANA, Washington J. TOMCSIK, Basel

R. TULASNE, Strasbourg E. UEHLINGER, Zurich H. UNGAR, Jerusalem B. WALTHARD. Bern M.WELSCH, Liège A. WERTHLMANN, Basel K. C. W1NKLER, Utrecht REDACTORES A. v. ALBERTINI, Zurich A. GRUMBACH. Zurich H. MOOSER, Zurich Vol. 18

1955

\section{BASEL (Schweiz) S. KARGER NEW YORK}

Alle Rechte, insbesondere das de $\Gamma$ Übersetzung in fremde Sprachen, vorbehalten.

Ohne ausdrückliche Genehmigung des Verlages ist es auch nicht gestattet, diesen Band oder

Teile

daraus auE photomechanischem Wege (Photokopie, Mikrokopie) zu vervielfältigen.

(C)

Copyright 1955 by S. Karger A.G., Basel. Printed in Switzerland by Buchdruckerei Friedrich Reinhardt AG., Basel Cliches : Aberegg-Steiner \& Cíe. AG., Bern, und Steiner \& Cie. AG., Basel

Index

Aibettini, A. v.: Zuү Pathogenese des experimentellen Methylcholanthrenkrebses deГ Maushaut 1176

Diskussion: Studer, Nicod, v. Albertini (Schlußwort).

Alvarez, R. R. de, vide D. V. Brown.

Arber, W., und E. Kellenberger: Untersuchung de $\Gamma$ Feinst $\Gamma$ uktur eines Bakteriophagen mit Hilfe von oxydativem Abbau 1118

A tiëns, E. J., and A. M. Simonis: The biosynthesis of folic-acid homologues from amino-carboxy-pyridine and other para-amino-benzoic-acid substitutes by E. coli $\quad 71$ Aufdermaur, M., und H. Brodhage: Tierexperimentelle Untersuchungen mit BCG und Harastoff vorbehandelten Tuberkelbazillen 
Diskussion: Zollinger, Rutishauser, Nicod.

Barner, F. R.: Giomeruläre Thrombose und Sklerose bei Phäochromozytom . 80

Bárta, K., G. Dvorácek und A. Kadlec: Komplementbindungs-Reaktion bei Pneumozysten-Pneumonien 22

Benic, V., vide H. Weisglass.

Berman, Ch.: Nutritional States in the Causation of Primary Liver Cancer . . 598

Be\&taková, Z., vide F. Wagner.

Bingel, K.F.: Über epidemiologische Verlaufsformen des Scharlachs .... 1043

Blum, F., und W. Taterka: Mikrobiologische Probleme zur Ätiologie des ende-

mischen Kropfes 32

Bonifas, V., vide E. Grasset.

Bonser, G. M., and G. M. Thomas: Data Relevant to the Apparently Rising In

cidence of Lung Cancer in Great Britain and to the Effects of Treatment

on Survival 885

Bonslcin, H.: Un cas de maladie de Letterer-Siwe chez le nouveau-né . . 1257 Discussion:

Zollinger, Rutishauser, Nicod, Werthemann.

Bormann, F. von: Scharlachausbreitung auf der Erde als ein klimatologisch

bedingtes botanisches Problem 1039

Braun, H.: Zur Frage des Verwendungsstoffwechsels des Typus humanus und des Typus bovinus des Mycobacterium tuberculosis 989

Briellmann, A.: Über Plasmazellenbefunde in Lymphknoten bei Lebercirrhosen

und die Bedeutung der Russelschen Körperchen 335

Briggs, M. E., vide F. Reiss.

Brodhage, H., vide M. Aufdermaur.

Brown, D. V., and R. R. de Alvarez: Long-Range Studies of the Biologic Be havior of the Human Uterine Cervix. I. The Incidence of Metaplasia in

Presumably Healthy Women Biopsied at Six-Month Intervals During a

Three-Year Period 781

Brunner, H. E.: Spätschäden nach diagnostischer Thorotrastanwendung . 170

- vide /. R. Rüttner.

Bucher, V.: Befunde nach experimentellen Gelenkknorpeldefekten beim Meerschweinchen 185

Bürki, F., Chr. Margadant und W. Mosimann: Diagnose der Rinderbrucellose

durch einen Kutantest mit einem Polysaccharid-Allergen aus Brucella abor

tus. 1. Mitteilung: Bestimmung der Gebrauchsdosis 1147

- vide E. Wiesmann.

Casper, J.: Incidence of Uterine Cancer Among Different Ethnic Groups . . 764 Celjuska, L.,

vide $H$. Weisglass.

Clemmesen, J.: On the Interrelation between Mammary and Uterine Cancer . 717

- $\quad$ and A. Nielsen: The Geographical and Racial Distribution of Cancer of the

Lung 803

Correa, P.: Statistical Study of Cancer in Antioquia 491

Cottier, H.: Vorhofseptumaneurysmen bei kongenitalen Herzfehlern . . .1178

Diskussion: Rutishauser, Cottier (Schlußwort). Cutler, S. J.: The Probability of Developing Lung

Cancer for Smokers and

Non-Smokers 902 
Czgzewski, K., vide F. Milgrom.

Davies, J. N. P.: Primary Liver Carcinomas in Uganda Africans 661

- Nutritional States as Causal Factors of Cancer 416

Delarue, J.: Anatomie pathologique des cancers broncho-pulmonaires . . 820

Belong, V.: Gargoylismus 318

Denoix, P. F.: La frequence du cancer du foie dans le monde

564

Dietrich, F. M.: Über die Einzellisolierungsmethode nach Lederberg . . 369 Domianns, E.:

Reitrag zur Frage der Zunahme der Krebskrankheit mit be-

sonderer Berücksichtigung des Lungenkrebses 907

Dorn, H. F.: The Incidence of Primary Cancer of the Liver in the Negro in

Africa and the United States ., . 648

The Incidence of Cancer in the United States 409

vide L. J. Dunham.

Dosch, F.: Morphologie und Pathologie homologer Doppelinfekte des Hühner-

eies 104

Dungal, N.: Cancer in Iceland, with Special Reference to Stomach Cancer . . 550 Dunham, L. J., and H. F. Dorn: Techniques in the Geographic Pathology of

Cancer 472

Dvofácek, C, vide K. Bårta.

Edmondson, H. A.: Pathology of Cancer of the Liver in the United States of

America 653

Einfalt, W. A.: Internationale Sektionsstatistik, Notwendigkeit und Möglichkeit 946

Essellier, A. F., vide H. R. Marti.

Falkiewicz, A., vide F. Milgrom.

Farreras Valenti, P.: Die pneumopathische endostale Osteosklerose .... 143

Fey, H.: Versuch einer Deutung des Prozonenmechanismus mit Hilfe eines «umgekehrten Blockingtestes». 1. Mitteilung

8

- vide E. Wiesmann.

Fiechter, A.: Über das Gärvermögen von belüfteten Kulturen der Weinheferasse

«Herrliberg» 981

Fischer, E.: Die zahlenmäßige Häufigkeit der verschiedenen Hefen im mykologischen Untersuchungsmaterial 1

Flamm, H.: Untersuchungen über die diaplazentare Übertragung des CoxsackieVirus ,"..'.. 16

- Die patho-histologische Diagnose der Listeriose im Tierversuch .... 270

Gäumann, E.: Welketoxine und Welkekrankheiten bei Pflanzen 1111

Gagnon, F.: Marital Status and Pregnancy in the Causation of Cancer of the

Cervix Uteri 755

Gardiol, D.: La necrose de la papule rénale chez le nouveau-né et le nourrisson.

Etude anatomo-clinique de 4 cas 1212

Discussion: Werthemann, Nicod, Gardiol (conclusion).

Gault, E. W.: The Geographic Distribution of Carcinoma of the Uterus and Rela

tive Distribution of Cervical and Fundal Carcinoma with Special Reference

to South India a .' 732

Gfeller, P., M. Rutishauser und T. Wikén: Über die Verwertung der Essig- und

n-Ruttersäure durch Clostridium beijerinckii Donker in Sulfitablauge . . 953 
Glauser, 0.: Über tumorförmiges Amyloid der Lungen. Beitrag zur dystopischen Knochenbildung 42

Gloor, F., und A. Werthemann: Über Leberveränderungen bei kongenitaler zystischer Pankreasfibrose 1244

Diskussion: Zollinger, Rutishauser, Riniker, Werthemann, Gloor und Werthemann (Schlußwort).

Graber, H., vide P. Kästli.

Schindler, H., vide C. Steffen.

Schornagel, H. E., vide M. Straub.

Schweizer, R., vide E. Wiesmann.

Segi, M.: Geographical and Racial Distribution of Cancer of the Breast . . 668

Siebenmann, R. E.: Invasiv wachsendes, vorwiegend basophiles Adenom des

Hypophysenvorderlappens bei Cushing-Rezidiv nach subtotaler Adrenektomie 1189

Simon, K., vide R. H. Regamey.

Simonis, A. M., vide E. J. Ariëns.

Simons, H. C. R.: Die kulturelle Züchtung des vermutlichen Erregers der mul-

tiplen Sklerose (Spirochaeta myelophthora Steiner 1931) in den USA. und

die Bedeutung der Desinlegrationsmethode mit Thedanblau-Kaliumchlorat

für den Nachweis von Spirochäten im Zentralnervensystem 1138

-· Kursversuche zur Erzeugung von Pseudospirochäten 1140

Steffen, C, und H. Schindler: Untersuchungen über die Eigenschaften einer im

Serum von Polyarthritikern und von Patienten mit rheumatischer Endo

carditis vorkommenden Substanz mit den Merkmalen eines gewebsspezifi-

schen Antikörpers 287

Steiger, U.: Beitrag zur pathologischen Histologie der Brucellosen beim Menschen 303

Steiner, P. E.: World Distribution of Cancer and the Etiological Significance of

Racial Studies 442

Stocks, P.: Social Status in Relation to Carcinoma of the Breast 706

Straub, M., and H. E. Schornagel: Pathology Figures from the Netherlands

During and After the War 940

Strong, L. C: The Ageing of the Races of Mankind and Cancer $\quad 725$

Studer, A., vide G. Zbinden.

Stünzi, H.: Zur Pathologie des sog. Mastozytoms des Hundes 1271

Diskussion: Studer, Rutishauser.

Stundl, K.: Auswirkungen phenolhaltiger Abwässer auf Vorflut- und Grundwasser 1012

Swierczyńska, Z., vide F. Milgrom.

Takeda, K.: Cancer of the Stomach in Japan from the Viewpoint of Patho

logical Anatomy 538

Taterka, W., vide F. Blum.

Taylor, C. W.: Botryoid Tumours of Cervix and Vagina 802

Thomas, G. M., vide G. M. Bonser.

Tjokronegoro, S.: Choriocarcinoma in Indonesia 791 vide L. K. Joe.

Tromp, S. W.: Possible Effects of Geophysical and Geochemical Factors on

Development and Geographic Distribution of Cancer $\quad 929$

Vellios, Fr.: Tumours of the Breast: Their Occurrence in Thailand .... 722

Vien, N. L., vide B. Joyeux. 
Wagner, V., Z. Bestáková, V. Malý und M. Motlíková: Die Wirkung einiger Stoffe auf die Hämolyse und das Wachstum des Streptococcus pyogenes im Blutagar. Neue Modifikation des elektiven Nährbodens 278

Wantz, M., vide R. H. Regamey.

Weisglass, H., L. Celjuska und V. Benic: Einige Beobachtungen der Ultraschallwirkung auf menschliches Plasma 65

Werthemann, A., vide R. ïiefi.

- vide F. Gloor.

Weyer, F.: Einige Beobachtungen beim Nachweis von Psittakose oder Ornithose im Tierversuch 1105

Wheeler, J. D., vide A. T. Hertig.

Wiesmann, E., R. Schweizer, H. Fey und F. Biirki: Nachweis von Rickettsia

burneti bei Schaf, Ziege und Rind 1095

Wikén, T., und 0. Richard: Weitere Untersuchungen über die Bedeutung des

Sauerstoffs für die Vergärung der Glucose durch Weinhefe 970

Wikén, T., vide P. Gfeller.

Willy, W., vide J. R. Rüttner.

Wuhrmann, K., und /. Meyrath: Über die bakterizide Wirkung wäßriger Ozon-

lösungen $\quad 1060$

Zbinden, G., und A. Studer: Zur Wirkung von Vitaminen der B-Gruppe auf die experimentelle Isoniazid-«Neuritis» 1198

Grady, H. G.: The Pathologic Anatomy of Cancer of the Breast. A Summary of

the Replies to the Questionnaire of the International Society of Geographic

Pathology 685

Grasset, E., et V. Bonifas: Sur Tobtention de formes L de Klebsiella pneumoniae

en milieu liquide et chez la souris sous Taction de la pénicilline .... 1074

Hamperl, H.: Problems of the Geographic Pathology of Cancer 458

Haußmann, H. G.: Welche Virus-Encephalitiden kommen in Europa vor? . 1046 Hedinger,

Chr.: Endokrine Begleiterscheinungen der Karzinoide .... 1184

Diskussion: Werthemann, Hedinger (Schlußwort).

Henschen, F.: Hereditary Disease in the Four Nordic Countries 385

Hertig, A. T'., J. D. Wheeler, H. W. Home, Jr. and H. Mansell: The Pathologic

Anatomy of Uterine Carcinoma 750

Heß, R., und A. Werthemann: Zur Frage der Polymyositis 1251

Diskussion: Scheidegger, Zollinger, Heß (Schlußwort). Heyningen, W. E. van: Recent

Developments in the Field of Bacterial Toxins 1018 Higginson, J.: Relation of Carcinoma of the

Liver to Cirrhosis, Malaria, Syphilis

and Parasitic Diseases 625

Hiller, Chr.: Ein Beitrag zur Frage der thermolabilen Leibesantigene bei Alka-

leszens-Bakterien $\quad 985$

Home, H. W., Jr., vide A. T. Hertig.

Hou, P. C: Primary Carcinoma of the Liver in the Community of Hong Kong 657

- Bronchogenic Carcinoma in the Hongkong Community 907

Hug, H.: Über die Einschlüsse in den Langhansschen Riesenzellen, ihre Be-

ziehungen zur produktiven Tuberkulose und ihre genetischen Zusammen-

hänge 223 
Jaffe, R.: Chronic Myocarditis in Venezuela 942

Jallut, O.: Application de la méthode des fiches perforées à Гanalyse statistique des protocoles d'autopsies 1219

Joe, L. K., and S. Tjokronegoto: Hepatic Fibrosis or Cirrhosis in Children in

Djakarta . 941

Joyeux, B., and N. L. Vien: Study of Carcinogenic Factors in Buccopharyngeal

Tumors in South-Vietnam 562

Kadlec, A., vide K. Bårta.

Kästli, P., und H. Graber: Die Beeinflussung der Keimzahl der Milch durch

Euterinfektionen und durch die Hygiene bei der Milchgewinnung . . . 1006 Kellenberger, E.:

L'étude de la multiplication du bactériophage par des mé-

thodes morphologiques $\quad 1120$

et A. Ryter: Contribution à $\Gamma$ étude du noyau bactérien $\quad 1122$

vide W. Arber.

Khanolkar, V. R.: Habits and Customs as Causal Factors of Cancer . . 423 Kodousek, R.:

Beitrag zur Histochemie der elastolytischen Vorgänge in Elasto-

granulomen 93

Kohler, H., und W. Mosimann: Zur Differenzierung der Salmonellenantigene 996

Kradolfer, F.: Virushemmung im nativen Milieu 1112

Lagier, R., vide E. Rutishauser.

Langerock, G., vide /. H. Maisin.

Leupold, U.: Methodisches zur Genetik von Schizosaccharomyces pombe . . 1141

Lindenmann, J.: Automaüsche Pipettiervorrichtung für serologische Massen-

untersuchungen $\quad 1036$

Llombart, A.: General Characteristics of Spanish Cancerous Mortality and

Morbidity 919

Löffler, H.: Influenza: Epidemiologische Untersuchungen in der Schweiz im

Zeitraum 1952-1955 1056

Macklin, M. T.: Inheritance of Cancer in Man

Maisin, J. H., and G. Langerock: Racial Factors in the Causation of Carcinoma

of the Breast 690

Malý, V., vide F. Wagner.

Mansell, H., vide A. T. Hertig.

Margadant, Chr., vide F. Bürki.

Marsden, A. T. H.: Primary Carcinoma of the Liver in Malaya 644

- $\quad$ The Aetiology of Carcinoma of the Male Breast 728

Marti, H. R., A. F. Essellier und L. Morandi: Morphologisch-biologische Unter-

suchungen an eosinophilen Granulozyten 1164

May, J. M.: Geographic Pathology and Medical Ecology 482

Meyrath, J., vide K. Wuhrmann.

Milgrom, F., A. Falkiewicz and K. Czyzewski: Serological Studies on Pituitary

Graft 240

- $\quad$ and Z. Swierczyńska: Studies on the Agglutination of Tuberculine-Coated

Red Cells 257

Molnár, J.: Diffuses alveoläres Lungenkarzinom 328

Morandi, L., vide H. R. Marti. 
Morawiecki, J.: Ein Beitrag zur antibakteriellen Wirkung des Speichels ... 38

Mosimann, W., vide F. Bürki.

- vide H. Kohler.

Motlíková, M., vide F. Wagner.

Mülhens, K.: Desinfektionsprobleme bei Fadenpilzen und Hefen .... 1069 Neuhold, R.:

Eígenartige Lokalisation von Paramyloidablagerungen bei diffuser

Plasmocytose 353

Neurdenburg, M. G.: On Carcinoma of the Stomach 507

Nielsen, A., vide J. Clemmesen.

Novel, E.: Une nouvelle méthode simple et rapide de coloration différentielle

des spores bactériennes 113

- $\quad$ Erythromycine et staphylocoques dorés. Résultats compares des tests de

sensibilité à $\Gamma$ érythromycine envers des souches autochtones isolées en

1953 et 19541087

- $\quad$ et E. Pongratz: Sensibilité actuelle du staphylocoque doré vis-à-vis des anti-

biotiques utilises habituellement 1091

Ober, W. B., and L. Reiner: Cancer of the Cervix in Jewish Women .... 774

Oberling, Ch.: What Can Experimentation Teach Us with Regard to the Geo

graphical Distribution of Cancer? 429

Otte, H. J.: Zum Problem der Bakteriämien nach Tonsillektomien . . . 1104 PachteГ, M. R.: Die

Herdnephritiden, thre Häufigkeit, Histologie, Klinik und

Pathogenese 198

Phillips, A. J.: Cancer Among Canadian Indians 500

Pongratz, E., vide E. Novel.

Regamey, R. H., K. Simon et M. Wantz: Prophylaxie du tétanos: injection associée de serum et d'anatoxine $\quad 1157$

Reiner, L., vide W. B. Ober.

Reiss, F., and M. E. Bríggs: Cultural Studies of Four Pathogenic Nocardia . 129

Richard, 0 , vide T. Wikén.

Rijssel, Th. G. van: The Increase of the Death Rate from Cancer of the Breast

in the Netherlands 731

Ringertz, N.: Environmental Factors and Smoking in the Causation of Cancer

of the Lung 866

Riniker, P.: Lymphangiocystofibrom des Ligamentum latum mit maligner Ent-

artung 1258

Rivas Roz, M.: Primitive Malignant Tumors of the Liver 666

Rosahn, P. D.: Cancer of the Lung in Thailand 898

Roth, W.: Ein Beitrag zur Identifizierung von Candida albicans 1001

Roulet, Fred. C: Anatomie pathologique du cancer primitif du foie . . 583 Rättner, J. R.:

Untersuchungen über die Kupfferschen Sternzellen der Leber . 1183 Rüttner, J. R., W. Willy und

H. E. Brunner: Die Gewebsreaktion auf kristallines

Aluminiumphosphat im Peritonealtest 115

Rutishauser, E., et R. Lagier: A propos de la Maladie de Dupuytren. . 1262

Discussion: Scheidegger, Nicod, Werthemann, Riniker, Rutishauser (conclusion). Rutishauser, M., vide P. Gfeller. Ryter, A., vide E. Kellenberger.

Saxén, E.: Report from the Finnish Cancer Registry 556 
Schapiro, M. M.: The Geographical Pathology of Neoplastic Disease in Honduras 486

Scheidegger, S.: Traumatische Spätapoplexie 1224

Diskussion: Nicod, Rutishauser, Scheidegger (Schlußwort).

Schindler, H., vide C. Steffen.

Schornagel, H. E., vide M. Straub.

Schweizer, R., vide E. Wiesmann.

Segi, M.: Geographical and Racial Distribution of Cancer of the Breast . 668

Siebenmann, R. E.: Invasiv wachsendes, vorwiegend basophiles Adenom des

Hypophysenvorderlappens bei Cushing-Rezidiv nach subtotaler Adrenektomie 1189

Simon, K., vide R. H. Regamey.

Simonis, A. M., vide E. J. Ariëns.

Simons, H. C. R.: Die kulturelle Züchtung des vermutlichen Erregers der mul-

tiplen Sklerose (Spirochaeta myelophthora Steiner 1931) in den USA. und

die Bedeutung der Desintegrationsmethode mit Thedanblau-Kaliumchlorat

für den Nachweis von Spirochäten im Zentralnervensystem 1138

-· Kursversuche zur Erzeugung von PseudospÎTOChäten 1140

Steffen, C, und H. Schindler: Untersuchungen über die Eigenschaften einer im

Serum von Polyarthritikern und von Patienten mit Theumatischer Endo

carditis vorkommenden Substanz mit den Merkmalen eines gewebsspezifi-

schen Antikörpers 287

Steiger, U.: Beitrag zur pathologischen Histologie der Brucellosen beim Menschen 303

Steiner, P. E.: World Distribution of Cancer and the Etiological Significance of

Racial Studies 442

Stocks, P.: Social Status in Relation to Carcinoma of the Breast 706

Straub, M., and H. E. Schornagel: Pathology Figures from the Netherlands

During and After the War 940

Strong, L. C: The Ageing of the Races of Mankind and Cancer $\quad 725$

Studer, A., vide G. Zbinden.

Stünzi, H.: Zur Pathologie des sog. Mastozytoms des Hundes 1271

Diskussion: Studer, Rutishauser.

Stundl, K.: Auswirkungen phenolhaltiger Abwässer auf Vorflut- und Grundwasser 1012

Swierczyńska, Z., vide F. Milgrom.

Takeda, K.: Cancer of the Stomach in Japan from the Viewpoint of Patho

logical Anatomy 538

Taterka, W., vide F. Blum.

Taylor, C. W.: Botryoid Tumours of Cervix and Vagina 802

Thomas, G. M., vide G. M. Bonser.

Tjokronegoro, S.: Choriocarcinoma in Indonesia 791 vide L. K. Joe.

Tromp, S. W.: Possible Effects of Geophysical and Geochemical Factors on

Development and Geographic Distribution of Cancer $\quad 929$

Vellios, Fr,: Tumours of the Breast: Their Occurrence in Thailand .... 722

Vien, N. L., vide B. Joyeux.

Wagner, V., Z. Bestóková, V. Malý und M. Motlíková: Die Wirkung einiger Stoffe auf die Hämolyse und das Wachstum des Streptococcus pyogenes im Blutagar. Neue Modifikation des elektiven Nährbodens 278 
Wantz, M., vide R. H. Regamey.

Weisglass, H., L. Celjuska und V. Benic: Einige Beobachtungen der Ultraschallwirkung auf menschliches Plasma 65

Werthemann, A., vide R. Heß.

- vide F. Gloor.

Weyer, F.: Einige Beobachtungen beim Nachweis von Psittakose oder Ornithose im Tierve $\Gamma$ such 1105

Wheeler, J. D., vide A. T. Hertig.

Wiesmann, E., R. Schweizer, H. Fey und F. Bürki: Nachweis von Rickettsia burneti bei Schaf, Ziege und Rind 1095

Wikén, T., und 0. Richard: Weitere Untersuchungen über die Bedeutung des

Sauerstoffs für die Vergärung der Glucose durch Weinhefe 970

Wikén, T., vide P. Gfeller.

Willy, W., vide J. R. Rüttner.

Wuhrmann, K., und /. Meyrath: Über die bakterizide Wirkung wäßriger Ozonlösungen $\quad 1060$

Zbinden, G., und A. Studer: Zur Wirkung von Vitaminen der B-Gruppe auf die experimentelle Isoniazid-«Neuritis» 1198

Marti, H. R., A. F. Essellier und L. Morandi: Morphologisch-biologische Untersuchungen an eosinophilen Granulozyten 1164

May, J. M.: Geographic Pathology and Medical Ecology 482

Meyrath, J., vide K. Wuhrmann.

Milgrom, F., A. Falkiewicz and K. Czyzewski: Serological Studies on Pituitary

Graft 240

- $\quad$ and Z. Swierczy Red Cells 257

Molnct $\Gamma$, J.: Diffuses alveoläres Lungenkarzinom 328

Morandi, L., vide H. R. Marti.

Morawiecki, J.: Ein Beitrag zur antibakteriellen Wirkung des Speichels ... 38

Mosimann, W., vide F. Bürki.

- vide H. Kohler.

Motlíková, M., vide F. Wagner.

Mülhens, K.: Desinfektionsprobleme bei Fadenpilzen und Hefen . . . 1069

Neuhold, R.: Eígenartige Lokalisation von Paramyloidablagerungen bei diffuser

Plasmocytose 353

Neurdenburg, M. G.: On Carcinoma of the Stomach 507

Nielsen, A., vide J. Clemmesen.

Novel, E.: Une nouvelle méthode simple et rapide de coloration différentielle

des spores bactériennes

- Erythromycine et staphylocoques dorés. Résultats compares des tests de sensibilité à $\Gamma$ érythromycine envers des souches autochtones isolées en 1953 et 1954 ..." 1087

- $\quad$ et E. Pongratz: Sensibilité actuelle du staphylocoque doré vis-à-vis des antibiotiques utilises habituellement 1091 
Ober, W. B., and L. Reiner: Cancer of the Cervix in Jewish Women .... 774

Oberling, Ch.: What Can Experimentation Teach Us with Regard to the Geo graphical Distribution of Cancer? 429

Otte, H. J.: Zum Problem der Bakteriämien nach Tonsillektomien . . 1104 Pachter, M. R.: Die

Herdnephritiden, ihre Häufigkeit, Histologie, Klinik und

Pathogenese 198

Phillips, A. J.: Cancer Among Canadian Indians $\quad 500$

Pongratz, E., vide E. Novel.

Regamey, R. H., K. Simon et M. Wantz: Prophylaxie du tétanos: injection as-

sociée de serum et d'anatoxine $\quad 1157$

Reiner, L., vide W. B. Ober.

Reiss, F., and M. E. Briggs: Cultural Studies of Four Pathogenic Nocardia . . 129

Richard, 0 , vide T. Wikén.

Rijssel, Th. G. van: The Increase of the Death Rate from Cancer of the Breast

in the Netherlands 731

Ringertz, N.: Environmental Factors and Smoking in the Causation of Cancer

of the Lung 866

Riniker, P.: Lymphangiocystofibrom des Ligamentum latum mit maligner Entartung 1258

Rivas Roz, M.: Primitive Malignant Tumors of the Liver 666

Rosahn, P. D.: Cancer of the Lung in Thailand 898

Roth, W.: Ein Beitrag zur Identifizierung von Candida albicans 1001

Roulet, Fred. C: Anatomie pathologique du cancer primitif du foie . . 583 Rüttner, J. R.:

Untersuchungen über die Kupfferschen Sternzellen der Leber . 1183 Rüttner, J. R,, W. Willy und H. E. Brunner: Die Gewebsreaktion auf kristallines

Aluminiumphosphat im Peritonealtest 115

Rutishauser, E., et R. Lagier: A propos de la Maladie de Dupuytren . . 1262 Discussion:

Scheidegger, Nicod, Werthemann, Riniker, Rutishauser (conclusion). Rutishauser, M., vide P.

Gfeller. Ryter, A., vide E. Kellenberger.

Saxén, E.: Report from the Finnish Cancer Registry 556

Schapiro, M. M.: The Geographical Pathology of Neoplastic Disease in Honduras 486

Scheidegger, S.: Traumatische Spätapoplexie 1224

Diskussion: Nicod, Rutishauser, Scheidegger (Schlußwort).

ZoUinger, H. U.: Autoptische und experimentelle Untersuchungen über Lipoid-

nephrose, hervorgerufen durch chronische Quecksilbervergiftung . . 155

- Zu $\gamma$ Histologie und Dignität infiltrativ wachsender Fettgewebsgeschwülste.

Infiltrative Lipome und Liposarkome 1228

Diskussion: Werthemann, Hedinger, v. Albertini, Rutishauser, ZoUinger (Schlußwort).

A. Grumbach zum 60. Geburtstag 255

GESELLSCHAFTSBERICHTE - SOCIETY TRANSACTIONS - SOCIËTËS

Verhandlungen der 5. Konferenz der Internationalen Gesellschaft für Geogra-

phische Pathologie. - Comptes Rendus de la 5e Conference de la Société

Internationale de Pathologie Géographique. - Transactions of the 5th Meeting

of the International Society of Geographical Pathology. Washington, D.C.,

6.-11. September $1954 \quad 379$ 
Schweizerische Mikrobiologische Gesellschaft. 14. Jahresversammlung, 18. und 19. Juni 1955, in Zurich. - Société Suisse de Microbiologie. 14e assemblée annuelle, les 18 et 19 juin 1955, à Zurich 951

Mitglieder-Liste der Schweizerischen Mikrobiologischen Gesellschaft - Mem-

bres de la Société Suisse de Microbiologie 1167

Freie Vereinigung der Schweizer Pathologen. 21. Jahresversammlung in Locarno, 22. und 23.

Oktober 1955. - Association Libre des Pathologistes Suisses, 21e Assemblée annuelle à

Locarno, les 22 et 23 octobre $1955 \ldots 1175$

BUCHBESPRECHUNGEN - BOOK REVIEWS - LIVRES NOUVEAUX

123, 253. 376, 1172

VARIA 128,11 